\title{
MODEL ALTERNATIF \\ PENDIDIKAN ISLAM TRANSFORMATIF \\ (Studi Nilai-Nilai Pendidikan Islam dalam Tradisi \\ Ambengan Pada Peringatan Hari Besar Islam di \\ Desa Brunorejo Purworejo)
}

\author{
Dadan Ridwan \\ KUA Loano 1, Purworejo, Jawa Tengah \\ Email : dadanridwanmnj@gmail.com
}

\section{Abstract}

This paper critically describe and analyze the educational values of Islam contained in Ambengan tradition held in the village Brunorejo, Bruno, Purworejo. Ambengan tradition in the village of Brunorejo can be used as a medium of education Islam transformative. The values contained in the Islamic Education in Ambengan tradition is the educational value of faith, the value of moral education and social educational value. These educational values contained within the symbols contained in equipment implementation in Ambengan tradition and its the procession. The educational values that have deep meaning as the local wisdom expected to be able to reduce radicalism included in public life today. As a result of a culture based on religion, it is expected to be able to continue to be developed as a medium for the internalization of values education in the community. So it will be able to be absorbed and translated in public life.

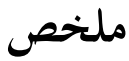

وتصف هذه الورقة القيم التربوية الإسلامية الواردة في تقليدأمبيعانالذي عقد في قرية برونوريجو في كيكاماتانبرونو كابوباتينبوروريجووتحللها نقديا.تقليدبرونوريجو يمكن أن يستخدم كوسيلة التعليم الإسلامي التحولي .القيم التربوية الإسلامية الواردة في تقليدأمبيعاهي التربويةالاجتماعية .هذه القيم التربوية المتضمنة في الرموز الواردة فيمعدات تنفيذ أمبيعانوين موكبه. هذه القيم التربوية لما معنى عميق كحكمة محلية لإنقاص التطرف 


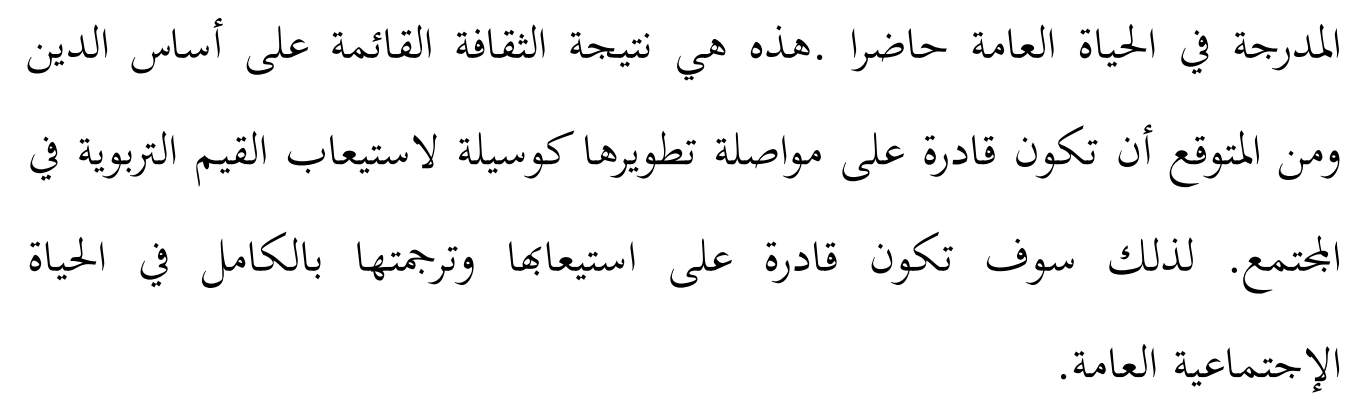

Keywords: Tradisi Ambengan, Nilai-nilai Pendidikan, Transformatif Budaya

\section{A. Pendahuluan}

Islam adalah agama kitab suci yang mengklaim diri sebagai penerus dan penyempurna tradisi Judeo-Kristiani. Pada gilirannya ia membangun tradisi baru yang berintikan jalinan tiga sendi, yaitu iman (percaya), Islam (berserah diri), dan ihsan (berbuat baik). Dari sini berkembang seperangkat sistem kepercayaan, ritual, dan etik behavioral yang kompleks namun penerapannya bisa lentur sehingga dalam batas-batas tertentu ada ruang yang cukup bagi terjadinya proses adopsi, adaptasi, dan akomodasi secara jenius dengan budaya lokal. Dengan demikian, walau inti ajaran Islam sama namun artikulasinya bisa berbeda sesuai dengan konteks lokal dan sosial dimana pemeluknya tinggal dan berada. ${ }^{1}$

Seperti juga agama lain, Islam adalah kekuatan spiritual dan moral yang mempengaruhi, memotivasi, dan mewarnai tingkah laku individu. Menguraikan tradisi Islam yang tumbuh di kelompok masyarakat tertentu adalah menelusuri karakteristik Islam yang terbentuk dalam tradisi populer. Pada titik ini, persoalan yang segera ditemui adalah unsur pembentuk tradisi tersebut dan, yang lebih penting lagi, unsur pembentuk 'Tradisi Islam' itu. ${ }^{2}$ Disini dapat diaplikasikan bahwa istilah "tradisi" secara umum dipahami sebagai pengetahuan, doktrin, kebiasaan, praktek, dan lain-lain yang diwariskan turun temurun termasuk cara penyampaian pengetahuan, doktrin dan praktek

1 Muhaimin AG, Islam dalam bingkai Budaya Lokal potret dari Cirebon, (Jakarta: PT. Logos Wacana Ilmu), 2002, hal.ix

2 Ibid. hal. 11 
tersebut. ${ }^{3}$ Selanjutnya, tradisi Islam merupakan segala hal yang datang dari atau dihubungkan dengan atau melahirkan jiwa Islam.

Islam sebagai agama yang banyak dianut bangsa Indonesia secara tidak langsung juga memberikan pengaruh besar dalam aspek kegiatan sehari-hari, dalam hal ini bagi masyarakat Islam yang ada di Jawa umumnya dan khususnya diDesa Brunorejo Kec. Bruno. Nilai-nilai agama Islam tersebut sudah merupakan harga yang tidak bisa ditawar-tawar lagi, ini terlihat dalam kegiatan bersifat sosial kemasyarakatan maupun keagaamaan. Baik dalam perayaan pernikahan, khitanan, aqiqahan (cukur rambut), walimatussafar (selamatan berangkat haji), kematian dan haulan (peringatan kematian seseorang) sampai acara selamatan boyongan rumah dll. Juga tradisi yang bersifat keagamaan, seperti perayaan hari besar Islam : Idul Fitri, Idul Adha, 1 Muharram, 10 Muharram (Asura), Muludan (Maulid Nabi Muhammad), Rajaban (peringatan Isra Mi'raj), Nisfu Sya'ban, menyambut bulan suci Ramadhan serta Nuzulul Qur'an. Semua kegiatan tersebut dilakukan sebagai tradisi dengan berbagai rangkaian ritual keagaamaan. Semua kegiatan tersebut selalu diisi dengan pembacaan tahlil dan do'a. Ada juga tradisi "bersihan" dalam hal ini salah seorang warga atau sekelompok warga masyarakat yang hendak melakukan suatu kegiatan selalu diawali dengan bersihan, yaitu berupa ziarah kubur ke makam leluhur (orang tua atau orang yang dikeramatkan/dimulyakan) tentu saja dengan membaca tahlil dan ditutup dengan do'a. Rasanya ada sesuatu yang kurang manakala warga masyarakat membuat acara atau kegiatan tanpa didahului bersihan atau setidaknya adanya bacaan tahlil didalamnya. Hal ini pula yang menjadikan tradisi tersebut seakan "wajib" bagi mereka untuk diadakan, dalam istilah masyarakat setempat "ora marem" atau "kurang afdhol". ${ }^{4}$

Masalahnya, bagaimanakah cara mengetahui bahwa tradisi tertentu atau unsur tradisi berasal dari atau dihubungkan dengan atau melahirkan jiwa Islam, yang kemudian menjadi Islam ? Dalam konteks ini, menarik mengacu pada Barth yang menandai hubungan antara tindakan dan tujuan interaksi manusia. Menurutnya: “...... akibat dari (tindakan dan) interaksi selalu bervariasi dengan maksud partisipasi individu, ${ }^{5}$

3 Funk and Wagnalls, Standard Desk Dictionary, (Cambridge : Harper and Row), 1984.

4 Hasil wawancara dengan Ky. Khalid (salah satu tokoh masyarakat) Ds. Brunorejo

5 Fredrik Barth, Balinese Worlds, (Chicago : The Universitiy of Chicago Press, 1993). 
Pemikiran Barth memungkinkan kita berasumsi bahwa suatu tradisi atau unsur tradisi bersifat Islam ketika pelakunya bermaksud atau ingin mengaku bahwa tingkah lakunya sesuai denganjiwa Islam. Tentu saja ini penyederhanaan yang berlebihan dan paling banter hanya memberi titik awal.

Konteks pernyataan diatas jelas merujuk pada statemen Nabi Muhammad SAW, lebih dari seribu tahun yang lalu, jauh sebelum Barth, Nabi Muhammad menyampaikan hal ini secara eksplisit. Nabi Muhammad antara lain bersabda bahwa sahnya perbuatan adalah adanya niat, dan nilai segala perbuatan kita tergantung pada niatnya. Jika sesuatu itu diniatkan untuk tujuan dunia, maka nilai keduniaan itulah yang didapat, sedangkan jika sesuatu itu diniatkan karena Allah, maka nilainya adalah ketaatan kepada-Nya. Ini pentingnya niat bagi seorang Muslim. ${ }^{6}$

Tulisan ini bertujuan untuk mendiskripsikan dan menganalisis secara kritis nilai-nilai pendidikan Islam yang terkandung dalam tradisi Ambengan yang dilaksanakan di Desa Brunorejo kec. Bruno Kab. Purworejo. Sebagaimana diketahui Desa Brunorejo yang notabene berada di daerah pegunungan berjarak $\pm 35 \mathrm{Km}$ dari Kota Kabupaten yang mayoritas masyarakatnya adalah petani. Warga desa Brunorejo dikenal masyarakat agamis yang berpegang teguh pada ajaran agama, hal tersebut dapat dilihat dari kegiatan keagamaan yang sering dilakukan masyarakat dan semarak, baik pada hari raya maupun Hari Besar Islam. Ada beberapa tradisi yang seringkali menyertai kegiatan keagamaan tersebut, yang menurut hemat penulis tradisi keagamaan tersebut bisa dijadikan sebagai media pendidikan Islam yang transformatif.

\section{B. Agama dan Tradisi Budaya}

Gambaran nilai-nilai agama dalam kehidupan masyarakat yang sudah tereduksi oleh nilai-nilai yang bersifat material-profan, seakan memunculkan anggapan bahwa agama sudah tidak penting lagi dalam kehidupan. Sebagaimana yang diungkapkan filosof barat Neztsee, bahwa "Tuhan sudah

6 "Innamal-'amalbil-niyatfainnalikulliimrii ma nawa..." hadis yang cukup panjang tapi luas, paling tidak bagian ini. Diriwayatkan oleh Muslim (Abu'l Husein Muslim bin al-Hajjaj bin Muslim al-Qushayriy al-Naisabury), periwayat hadis paling sahih. Hadis ini terdapat pada halaman pertama koleksi 40 hadis mulia Nawawi, dengan demikian tak perlu penjelasan mengenai kedudukan dan pengaruhnya terhadap pandangan Muslim Jawa. Teks lengkap hadis ini lihat Dahlan, A, Hadits Arba'in Annawawiyyah, (Bandung: Al-Ma'arif), 1988. 
mati". Anggapan ini berangkat dari pemikiran kegersangan spiritual yang terbangun pada masyarakat modern, khususnya masyarakat industri, yang seringkali mengedepankan rasional untuk menyelesaikan masalah, tanpa sama sekali menoleh sisi spiritual (agama) untuk menjadi acuan. Menurut Taufik Hidayat dalam tulisannya Memeluk Islam Sebagai Kesadaran Hidup, bahwa dalam masyarakat industrialisasi hakekat tentang hidup dipengaruhi oleh beberapa nilai yang melingkupinya sebagai suatu sistem yang kompleks. Bahwa suatu nilai tersebut juga tidak terlepas dari pemahaman agama yang ia anut, sistem sosial yang terbentuk dan kebudayaan yang ada. Bagi sistem sosial yang tidak berlandaskan pada agama sebagai sumber nilai dalam sistem itu, maka apalagi memisahkan agama dalam kehidupan keseharian, maka bisa dipastikan bahwa konstruksi sosial kemasyarkatannya akan berbeda dengan suatu sistem yang itu terbentuk karena hasil interaksi dan bersumber pada nilai moral dan etis yang bersumber pada agama. ${ }^{7}$ Lebih lanjut Taufiq Hidayat menjelaskan, bagi sistem sosial yang menghilangkan peran agama dalam membentuk nilai-nilai kemasyarakatannya (sekulerisme), maka bisa ditebak bahwa akan berkembang pandangan bahwa persoalan hidup di dunia tidak bisa diselesaikan dengan himbauan-himbauan agama. Bahwa hidup manusia adalah merupakan sesuatu yang nyata, ada, dan profan serta harus dipisahkan dengan yang sakral- yang sementara ini dimaknai sebagai salah satu nilai dalam agama. Dari pandangan seperti inilah terjadi suatu keadaan-dimana juga merupakan ekses dari modernisasi- yaitu dehumanisasi, kemerosotan moral, alienasi dan menafikan keberadaan Tuhan dalam kehidupannya. ${ }^{8}$

Hal tersebut tentunya lain bila suatu sistem sosial tidak menghilangkan agama sebagai sesuatu nilai yang baik. Nilai-nilai semacam inilah yang justru menjadi guidance dalam membawa kemajuan untuk membangun peradaban manusia ke arah yang lebih baik dan benar. Bahwa dalam hidup dan membangun peradaban, dimensi-dimensi moral dan etis sebagai pesan agama menjadi pandangan-pandangan dasar (the ground of meaning) yang menjadi landasan hidup dan mengilhami segala kehidupannya. Religiusitas yang diwujudkan dalam prilaku sehari-hari, seakan membuktikan bahwa sebenarnya manusia

7 Taufiq Hidayat, Memeluk Islam sebagai Kesadaran Hidup, dalam kumpulan tulisan Ruh Islam dalam Budaya Bangsa; Agama dan Problema Masa Kini, (Jakarta: Yayasan Festival Istiqlal, 1996), hal. 121

$8 \quad$ Ibid. hal. 122 
secara intrinsik selalu cenderung kepada kebenaran-kebenaran sejati (Q.S.30:30). Dan kebenaran sejati itu berasal dari Tuhan Yang Satu. Jadi pada dasarnya agama itu potensi suci Tuhan (al-fithrah) yang terderivasi atau pemilikan yang suci dan terdalam (inner sanctum) pada manusia. Oleh karena itu, tanpa perlu adanya pemaksaan kepada manusia, maka sebenarnya manusia yang hidup adalah manusia yang beragama. Disinilah letak dari makna agama (Islam) sebagai kesadaran hidup. Yaitu selalu menjalankan kehidupan di dunianya berdasarkan pada petunjuk Alqur'an dan ketauladanan dari Nabi Muhammad SAW.

Memang diakui bahwa agama sangat berperan dalam perkembangan masyarakat. Weber menekankan fungsi sosial dari agama, yakni memberi acuan makna bagi manusia untuk mendekati dunia dan masyarkat. Durkheim menekankan pada hakekat sosial dari agama. Yaitu memandang agama sebagai faktor penting bagi identitas dan integrasi masyarakat. Dari definisi fungsional agama ini, ia melihat agama berfungsi memberikan acuan makna serta sistem simbol untuk menginterpretasikan dunia dan keberadaan masyarakat di dalamnya. Oleh Talcot Parson, agama berperan secara kultural dalam pembentukan kesadaran dan hati nurani masyarakat. Peter L. Berger memandang bahwa agama sebagai yang berurusan dengan realitas suci yang mengatasi dimensi waktu. Agama bagai tudung suci yang melindungi manusia dari kelemahan eksistensialnya yang dilambangkan dengan kematian. Agama adalah usaha murni untuk membangun kosmos suci. ${ }^{9}$

Penggunaan agama sebagai sistem acuan nilai bagi sikap dan tindakan dapat mengarah pada peneguhan integrasi masyarakat, khususnya pada masyarakat yang beragama homogen dan memahaminya secara homogen pula. Namun, konflik (atau bahkan disintegrasi) bisa terjadi ketika kelompok tertentu pada masyarakat tersebut mengembangkan paham atau aliran keagamaan baru yang cenderung mengembangkan sistem acuan nilai sendiri. Dalam situasi inilah biasanya muncul ketidakrukunan di kalangan pemeluk suatu agama. Pada masyarakat yang heterogen dari segi agama, penggunaan agama sebagai sistem acuan nilai, dapat mengarah kepada konflik dan disintegrasi sosial, kecuali apabila masing-masing umat beragama dapat mengembangkan penafsiran keagamaan yang mempertemukan kesamaan yang terdapat pada

\footnotetext{
9 Peter L. Berger, Langit Suci, LP3ES, cet.II.1994.
} 
masing-masing sistem acuan. ${ }^{10}$

Tradisi kegamaan yang memungkinkan memunculkan rasa senang dan bahagia, ini juga merupakan salah satu kreasi pemeluk agama dalam menjalankan ibadah yang bersifat mahdah dan ghairu mahdah. Sistem nilai yang terkandung dalam ajaran agama seakan memberikan kesempatan seluasluasnya bagi pemeluknya untuk menjalankan ibadah sesuai keyakinan dan kemampuannya. Tentang hal ini pendapat Hujjatul Islam Abu Hamid alGhazali (450-505 H/ 1058-1111 M) menerangkan hakikat dari sekalian hakikat pandangan Islam, belaiu berkata: "Sesungguhnya sistem agama tidak akan terwujudkan kecuali dengan terwujudkannya sistem dunia. Ajaran agama, yaitu pengetahuan akan Allah SWT dan pelaksanaan ibadah kepada-Nya, tidak akan tercapai kecuali dengan sehatnya tubuh, adanya kehidupan, dan dengan tersedianya kebutuhan pokok, yaitu sandang, papan, pangan, dan keamanan." Kemudian Al-Ghazali melanjutkan:"Sesungguhnya, orang yang hatinya tenang, badannya sehat, dan mempunyai sembako untuk hari itu maka orang itu seakan telah mendapatkan dunia seluruhnya."

Ajaran agama tidak akan terlaksana tanpa terwujudkannya faktorfaktor yang primer ini. Jika tidak demikian, orang yang seluruh waktunya ia pergunakan untuk menjaga dirinya dari ancaman ketidakadilan dan hanya bisa mendapatkan sembako dengan menggunakan kekerasan, kapan ia dapat bekerja dengan tenang, sedangkan kedua hal itu jalan yang harus ditempuh untuk mendapatkan kebahagiaan akhiratnya? Dengan demikian, sistem duniawi, maksudnya sistem yang mengatur terpenuhinya kebutuhan dasar individu, adalah syarat bagi terwujudkannya ajaran agama. ${ }^{11}$

Keberlangsungan tradisi keagamaan di masyarakat merupakan manifestasi dari pemahaman keberagamaan yang menggambarkan pula tentang pola sosial yang terbentuk. Seperti adanya keamanan sosial dan jaminan diri akan mencukupi faktor-faktor fundamental bagi keberadaan sosial manusia dan peradabannya, baik materi maupun immateri, dalam bentuk kesehatan tubuh, terjaminnya keselamatan diri, terpenuhi kebutuhan sandang, papan, dan pangan, hingga keamanan umum yang menghilangkan faktor-faktor penyebab ketakutan,

${ }_{10}$ Muhith. A. Karim dkk. Peta Kerukunan Jawa Timur (Umat Beragama di Indonesia), (Jakarta: Bagian Proyek Peningkatan Pengkajian Kerukunan Hidup Umat Beragama Pusat Litbang Kehidupan Beragama Depag RI, 2002), hal.202

11 Al-Iqtishad fi al-I'tiqad, (Kairo: Maktabah Shubaih), hal. 135. 
kegelisahan, dan kekhawatiran dari kehidupan manusia. Seluruh hal itu dimasukkan oleh pandangan Islam sebagai bagian dari hal-hal primer yang vital (dharurat) dan kebutuhan sekunder (hajat), tidak semata-mata hak individu atau faktor-faktor pelengkap (kamaliat). Pandangan Islam kemudian menjadikannya sebagai faridhah 'kewajiban' yang wajib dipenuhi dalam sebagai wadah bagi terselenggaranya kewajiban-kewajiban agama dan ritus-ritus ibadah. ${ }^{12}$

Senada dengan beberapa pandangan di atas seperti apa yang dikemukakan Weber yang menerangkan fungsi sosial dari agama, yakni memberi acuan makna bagi manusia untuk mendekati dunia dan masyarakat. Juga apa yang dilontarkan Taufik Hidayat yang memberikan makna agama (Islam) sebagai kesadaran hidup. Yaitu selalu menjalankan kehidupan di dunianya berdasarkan pada petunjuk Al-Qur'an dan ketauladanan dari Nabi Muhammad SAW. Dan juga pendapat Hujjatul Islam Abu Hamid al-Ghazali yang menegaskan tentang hakekat pandangan Islam "Sesungguhnya sistem agama tidak akan terwujudkan kecuali dengan terwujudkannya sistem dunia. Dalam hal ini penulis mencoba untuk mengeksplorasi nilai-nilai yang terkandung dari tradisi keagamaan yang berkaitan dengan Perayaan Hari-hari Besar Islam terutama Maulid Nabi Muhammad SAW dan Rajaban (Rajabiyah).

\section{Islam dalam Transformasi Budaya}

Perjalanan sejarah bangsa telah mengentaskan suatu tatapan mozaik kebudayaan yang dapat kita gambarkan sebagai jajaran dan terkadang perpaduan dari tradisi-tradisi: (a) Tradisi prasejarah atau tradisi asli dan lokal; (b) Tradisi Hindu-Budha; (c) Tradisi Islam; dan (d) Tradisi Barat atau Modern. Keseluruhan tradisi ini telah menjadi unsur dari dan suatu rumusan yang kemudian membangun entitas budaya Indonesia. Pembangunan entitas budaya semenjak tahapan kemerdekaan, pada saat mencari dan mengokohkan kebudayaan nasional, sampai dengan tahapan kontemporer dewasa ini ketika pembangunan memasuki era industri, informasi dan globalisasi yang lazim pula disebut sebagai era kebangkitan nasional II, telah mengalami pergumulan yang terkadang menegangkan (dalam kadar tertentu sampai merambat ke tegangan politis). Dapat diibaratkan tatanan mozaik kebudayaan terus mengalami

12 Muhammad Imarah, Islam dan Keamanan Sosial, (Jakarta: Gema Insan Press, 1999), hal. 31. 
dinamika secara berkelanjutan. Unsur-unsur ataupun sub-sub entitas budaya tidak seluruhnya melebur dalam satu rumusan tunggal. Realitas kebhinekaan betapapun harus diterima dengan kelapangan dada yang arif atau bijaksana. ${ }^{13}$

Sebagai sebuah bangsa kita merasakan betapa nuansa Islam telah memberi warna dan telah merasuk dalam peri hidup budaya bangsa, yang tentunya tidak sebatas budaya-budaya di kawasan pulau jawa, namun diperkirakan pada hampir sebagian besar kawasan Indonesia. Hal ini telah menapaki waktu cukup panjang, membangun proses kontinum kultural yang kita yakini belum akan berhenti hingga sekarang dan disini. Selagi para pemeluk Islam selaku aktor-aktor budaya baik pada tataran individual maupun kolektif sosial masih memiliki kesadaran tugas kekhalifahan dimuka bumi, bahkan didorong perwujudan diri sebagai "ummat terbaik" (khairu ummah), bangunan budaya bangsa bernuansa Islam itu akan terus berlanjut. Tidak seyogyanya dicekam kekhawatiran: "Islam menjadi disfungsional dan umatnya bakal terpuruk lantaran kegarangan industrialisasi dan globalisasi". ${ }^{14}$

Perasukan Islam kedalam berbagai budaya di Jawa telah berlangsung demikian rupa sehingga Islam tidak bisa lagi dipisahkan dari kehidupan masyarakat pendukung budaya-budaya tersebut. Terlihat, misalnya pada masyarakat Betawi sebagaimana diutarakan oleh Badri Yatim:"Seluruh masyarakat Betawi secara kultural merasa dirinya seorang muslim sama dengan Melayu, Minangkabau, Aceh dan sebagainya, tanpa Islam orang tidak disebut sebagai orang Betawi. Setiap aktivitas selalu dikaitkan dengan Islam."

Bahkan, seperti dinyatakan oleh Ridwan Saidi, sebutan orang Betawi, mereka menamakan dirinya "orang selam". Selanjutnya bisa dilihat pula dalam tulisan Meutiah Farida Hatta, tentang masyarakat nelayan Betawi di pantai Jakarta, dan tulisan-tulisan lainnya. Pengintegrasian Islam dengan budaya sebagaimana pada masyarakat Sunda (termasuk didalamnya Banten dan Cirebon), Jawa dan sudah barang tentu Madura. Boleh dikata Islam telah menjadi bagian jati diri mereka. Begitulah pengalaman sejarah menggambarkan, tatkala Islam harus bertemu dengan kebudayaan dan peradaban lain, ia tidak memilih sikap penolakan dan menampilkan eksklusifisme. Sikap yang ditujukan adalah menerima kebudayaan lain secara ramah dan melakukan asimilasi. ${ }^{15}$

\footnotetext{
13 H. A. Malik Fadjar, Visi Pembaruan Pendidikan Islam, (Jakarta: LP3NI, 1998), hal. 113.

14 Ibid, hal. 190.

15 H. A. Malik Fadjar, Visi Pembaruan... , hal. 191.
} 
Ada tiga pedoman bagi penyebarluasan dan pengembangan Islam. Pertama, orang menyeru atau mengajak orang lain kejalan Islam dengan "hikmah". Kedua, ialah menyampaikan dengan tutur bahasa yang baik (Mua'idzatul hasanah), dan yang Ketiga, ialah manakala harus terjadi adu argumentasi atau berdebat dengan cara yang baik pula. Jika kerangka ini digunakan, rasanya bukanlah suatu keanehan bila Islam mampu menyebar secara luas dan cepat, serta memberikan bekas-bekas Islam, termasuk para wali dan kyai, serta ulama, mengembangkan Islam dengan tidak lupa tetap memelihara harmoni dengan budaya setempat. "Para Wali (Wali Sanga) di pulau Jawa dalam mengembangkan agama Islam tidak mengimplementasikan Islam sebagai agama dengan garis keras tetapi melalui corak dan budaya setempat. Hasil dari implementasi tersebut melahirkan suatu sikap dan perilaku yang mempunyai filosofi lain sehingga tidak melahirkan paham yang ekstrim". ${ }^{16}$ Begitu antara lain, fenomena penyebaran Islam. Kiranya menarik pula bahwa proses Islamisasi di Jawa berlangsung melalui proses tradisi dialog. Penyebabnya adalah, tatkala Islam hadir di Jawa, ia harus sudah berhadapan dengan masyarakat yang telah mengenal agama, kebudayaan dan tradisi kenegaraan yang telah kokoh. Pola dialog ini memungkinkan terjadinya penyerapan unsur-unsur tradisi yang kemudian dikembangkan dalam konsep dan paradigma Islam. Sebaliknya, sistem nilai Islam dan moralitas Islam dengan mudah diserap oleh masyarakat Jawa yang telah memiliki tradisi keagamaan pra Islam. ${ }^{17}$

\section{Islam Sebagai Ruh Budaya}

Pendidikan formal maupun non formal merupakan salah satu kekuatan ampuh dan faktor strategis dalam membentuk serta mengembangkan budaya masyarakat, khususnya budaya yang mampu menyiapkan masyarakat menghadapi transformasi dan globalisasi. Tujuan Pendidikan Islam pada hakekatnya adalah membentuk peserta didik (masyarakat) agar mampu berkembang sebagai generasi "Khairu ummah" (beriman dan bertaqwa, dewasa dalam bersikap, mentalitas, daya pikir dan semangat hidup mandiri, kreatif, dinamis dan berakhlak karimah).

\footnotetext{
16 A. L. Tibawi, Islamic Education, (London: Luzac \& Company Ltd, 1972), hal. 28.

17 H. A. Malik Fadjar, Visi Pembaruan... , hal. 192
} 
Pertanyaan dan sekaligus pokok masalahnya adalah bagaimana mengembangkan lembaga-lembaga pendidikan Islam sehingga mampu menjadi semacam "lahan subur" tempat persemaian generasi baru yang tangguh dan sarat oleh bentukan serta binaan nilai-nilai pendidikan al-Qur'an. Artinya pendidikan Islam harus mampu: (1). Membebaskan akal peserta didik dari semua kekangan dan belenggu, (2). Membangkitkan indra perasaan peserta didik sebagai pintu untuk berfikir dan (3). Membekali berbagai macam ilmu pengetahuan yang dapat membersihkan akal dan meninggikan derajat peserta didik. ${ }^{18}$

Agaknya sudah sangat mendesak untuk mengambil langkah-langkah pengembangan yang transformatif, baik dari sisi mutu dan relevansi maupun efesiensi.Dalam hal ini langkah awal yang harus dilakukan adalah berupa reorientasi, rekonstruksi reformasi merupakan suatu keharusan. Dengan langkah strategis tersebut diharapkan agama di masa depan tetap berada dalam bingkai missi profetiknya, dibutuhkan pemahaman dan penghayatan yang utuh terhadap agama. Di bawah ini akan coba dijelaskan dengan mengikuti pemikiran R. Stark dan C.Y. Lock (dalam Roland Robertson, Agama dalam Analisa dan Interpretasi Sosiologis, 1988) yang mengungkap lima dimensi agama yang penting, yang terdiri dari dimensi keyakinan, praktek, pengalaman, pengetahuan dan konsekuensi.

Pertama, dimensi keyakinan. Dimensi ini berkaitan dengan seperangkat kepercayaan dan keyakinan seseorang terhadap suatu ajaran yang bersumber dari Realitas Yang Mutlak. Inilah dimensi yang sangat dipentingkan oleh setiap agama. Di dalam Islam misalnya, terdapat penekanan yang demikian kuat agar setiap muslim mempunyai aqidah (sistem kepercayaan dan keimanan) yang kokoh yang tidak mudah dipengaruhi oleh aqidah yang lainnya. Karena demikian sentralnya kedudukan aqidah ini, dalam pendidikan agama (Islam) menjadi prioritas utama yang perlu diajarkan disamping syariah dan akhlaq. ${ }^{19}$

Kedua, dimensi praktek agama. Dimensi ini berkaitan dengan ketaatan seorang pemeluk agama dalam mengamalkan ajaran-ajaran agama terutama yang berbentuk ritual seperti shalat, puasa, zakat dan haji dalam Islam.

Ketiga, dimensi pengalaman. By definition, pengalaman agama merupakan tanggapan pemeluk agama yang melibatkan akal, perasaan dan kehendak hati

\footnotetext{
18 Ibid, hal. 176.

19 Ibid, hal. 187.
} 
terhadap apa yang dihayati sebagai Realitas Mutlak. Karena itu lebih banyak berhubungan dengan tingkat penghayatan, maka setiap orang merasakan pengalaman berbeda, meskipun Realitas Mutlak yang dihayati satu. Dalam melaksanakan shalat misalnya, meskipun secara bersama-sama orang melaksanakan ritus yang sama, menghadapi Realitas Mutlak yang sama, tapi masing-msing akan memperoleh pengalaman yang berbeda tergantung pada intensitas penghayatannya.

Ke-empat, dimensi pengetahuan atau intelektual. Pada dimensi ini mengacu kepada harapan bahwa orang-orang yang beragama paling tidak memiliki sejumlah, minimal pengetahuan mengenai dasar-dasar keyakinan, ritus-ritus, kitab suci dan tradisi-tradisi.

Kelima, dimensi konsekusensi. Jika dimensi pengalaman ini agama terletak pada personal experience (pengalaman pribadi), maka pada dimensi yang terakhir ini, keberagamaan diukur pada akibat yang ditimbulkan dalam kehidupan sosial. Di sini agama diharapkan memberikan pengaruh secara nyata dalam kehidupan sosial manusia. Karenanya dilihat pada dimensi terakhir ini, agama tidak mandeg hanya pada dimensi keyakinan, ritus, pengalaman, pengetahuan yang semuanya itu sangat bersifat pribadi. ${ }^{20}$

Kelima dimensi di atas tidak berdiri sendiri, tapi merupakan satu kesatuan yang utuh. Karena itu, kesempurnaan pemahaman dan penghayatan terhadap ajaran agama diukur dari kelima dimensi tersebut melalui transformasi pendidikan yang dilakukan melalui institusi lembaga pendidikan yang ada di masyarakat.

\section{E. Tauhid Yang Transformatif}

Dalam Islam dinyatakan bahwa suatu perbuatan baru dikatakan bermakna jika dilandaskan pada keimanan. Tanpa iman, perbuatan apa pun akan sia-sia di hadapan Allah SWT. Itu sebabnya, kewajiban pertama bagi manusia adalah beriman terlebih dahulu sebelum dia melakukan apapun.

Bila kaidah ini dipegang, maka setiap perbuatan bagi seorang mukmin, memiliki interaksi dan nilai ganda. Yang pertama dalam hubungannya dengan Allah yang dengan itu pekerjaan tersebut mempunyai nilai ibadah

\footnotetext{
20 Ibid, hal. 189.
} 
yang dijanjikan pahala di akhirat. Yang kedua, dalam hubungannya dengan sesama manusia yang dengan itu pekerjaan tersebut mempunyai nilai manfaat duniawi. ${ }^{21}$ Karena didasarkan atas keimanan kepada Allah, maka perbuatan yang dilakukan oleh seorang mukmin pasti dimaksudkan untuk memberi manfaat yang sebesar-besarnya kepada umat manusia, dan tidak dibenarkan untuk tujuan merusak. Dari ini kita dapat menarik kesimpulan balik bahwa hanya pekerjaan yang dilakukan oleh orang tidak beriman sajalah yang mengandung unsur-unsur perusak.

Berdasarkan itu, kita melihat ajaran pertama yang ditanamkan oleh alQur'an al-Karim adalah keimanan kepada Allah SWT. Ajaran tersebut disebut ajaran tauhid, yakni meyakini dan mengakui Allah SWT sebagai Tuhan Yang Maha Esa dan tiada sekutu bagi-Nya. Orang-orang pertama yang menerima ajaran al-Qur'an yang diwahyukan kepada Nabi Muhammad Saw. tersebut adalah bangsa Arab yang sebelumnya disebut bangsa Jahiliyah. Istilah ini (jahiliyah) sering kali disederhanakan artinya dengan "kebodohan". Jahiliyah dengan arti seperti itu, berkonotasi "tidak pandai " atau "tidak mempunyai ilmu", yang dinisbatkan dengan bangsa Arab pra-Islam agaknya kurang tepat. Sebab, masyarakat Arab pra-Islam bukanlah masyarakat yang bodoh. Mereka, seperti yang dikemukakan oleh beberapa ayat al-Qur'an, adalah masyarakat yang memiliki pikiran yang tajam, pandai berbicara, mempunyai penyairpenyair yang ulung, pandai berdagang, dan lain sebagainya. ${ }^{22}$ Sekiranya mereka adalah orang-orang yang "bodoh", tentunya yang pertama-tama diturunkan oleh al-Qur'an untuk mengubah kondisi mereka adalah ayat-ayat yang berisi dorongan untuk mencari ilmu, dan bukan ayat-ayat yang berisi tentang keimanan. Memang benar bahwa ayat-ayat yang pertama diturunkan Allah SWT dalam surah al-'Alaq juga berkenaan dengan tulis-menulis. Akan tetapi keseluruhan ayat-ayat yang diturunkan pada periode Makkah (Makiyah) adalah ayat-ayat yang berisi ajaran tauhid.

Tauhid bukanlah keyakinan yang tersimpan dalam hati atau sekedar kalimat yang terucapkan melalui mulut. Dan juga bukanlah sekedar ilmu yang tersimpan dalam peti intelektualisme. Akan tetapi ia merupakan keyakinan

21 Afif Muhammad, Islam "Mazhab Masa Depan", Menuju Islam Non Sektarian (Bandung: Pustaka Hidayah, 1998), hal. 245.

22 Ibid, hal. 246. 
yang termanifestasikan secara total dalam kehidupan pemiliknya. Para ulama kita mendefinisikan iman dengan, Iqrârun bi al-lisân, wa I'tiqâdun bi al-jinân, wa'âmalun bial-arkân" (pengakuan dengan lisan, keyakinan dalam hati, dan amal dengan anggota tubuh). Lazimnya, kaum muslim memahami Iqrâr bi al-lisân dengan ucapan dua kalimat syahadat. Dengan pemahaman seperti itu, maka seseorang yang sudah mengucapkan dua kalimat syahadat dinyatakan sebagai Mukmin dan sekaligus Muslim. Tekanan yang kuat aspek formal ini, kadangkadang terasa berlebihan, dalam arti kita cenderung mengakui kemukminan dan keislaman seseorang dari syahadatnya. Sementara itu, keyakinan dalam kalbu adalah sesuatu yang sangat sulit dideteksi. Padahal kedua syarat di atas masih memiliki kelanjutan, yakni "beramal dengan anggota tubuh". ${ }^{23}$

Begitu pula halnya dengan amal perbuatan seorang Mukmin, ia mestinya mencerminkan keimanan dan keislaman dalam bentuknya yang total dan integral pula. Dalam kaitan ini kita sering kali masih melihat adanya sementara kaum Muslim yang memahami 'âmalun bi al-arkân ini sebagai ibadah kepada AllahSWT dalam bentuk shalat, puasa, dan sejenisnya. Padahal dalam haditsnya Rasulullah saw. mengatakan,: "Tidaklah disebut beriman seseorang di antara kamu sebelum dia mencintai sahabatnya seperti dia mencintai dirinya sendiri", dan "Barangsiapa beriman kepada Allah SWT dan hari akhir, hendaknya dia menghormati tetangganya", ${ }^{24}$ dan masih banyak hadits lain yang senada dengan itu. Makna dari semuanya itu adalah bahwa keimanan dan keislaman seseorang haruslah termanifestasikan dalam seluruh aktivitasnya sehari-hari: dalam shalat dan puasanya, dalam cara makan dan tidurnya, dalam cara berjalan dan duduknya, bahkan dalam cara buang hajat dan cara berpakaiannya. Kalau kaidah ini kita terima, maka kita dapat menyimpulkan bahwa, belumlah disebut sebagai Mukmin yang baik jika seseorang mengucapkan dua kalimat syahadat tetapi makan dengan tangan kiri. Tidaklah disebut Mukminah yang baik, seseorang perempuan yang telah mengucapkan dua kalimat syahadat tetapi sering ngerumpi, dan seterusnya. ${ }^{25}$

Sebagai seorang Mukmin, kita mesti memahami dan merasakan kehadiran nama dan sifat-sifat Allah dalam kehidupan kita. Artinya, beriman kepada

\footnotetext{
23 Ibid, hal. 247.

24 Al-hadits

25 Ibid. hal. 248.
} 
Allah dengan seluruh sifat-sifat-Nya tidaklah cukup dengan mengetahui bahwa Allah mempunyai sifat dua puluh yang kita hafalkan dari waktu ke waktu. Begitu pula dengan keimanan tentang adanya malaikat. Ia tidak cukup dengan mengetahui nama-nama para malaikat itu seperti yang selama ini dimiliki anak-anak kita. Artinya, jika kita memang beriman kepada malaikat Raqib dan 'Atid yang selalu mendampingi kita setiap saat, maka kehadiran mereka harus betul-betul terasakan. Kita sering menemukan mahasiswa atau pelajar yang menyontek ketika ujian, padahal mereka diajari beriman bahwa di kiri dan kanan mereka ada malaikat Raqib dan 'Atid. Keimanan seperti ini belum merupakan keimanan yang transformatif, tetapi baru merupakan keimanan formalistik. Dalam banyak aktivitas, keimanan kita kepada Allah dan rukun iman lainnya, masih terihat formalistik dan belum transformatif. Agar semua itu tertransformasikan dalam kehidupan sosial, maka sistem pendidikan dan pengajaran keimanan kita harus dilakukan dengan cara yang tepat. Pengajaran Tauhid yang selama ini lebih menekankan pada pengetahuan tentang sifat-sifat, tampaknya harus dilanjutkan dengan pemahaman yang dapat mengaktualisasikan sifat-sifat tersebut dalam kehidupan nyata. ${ }^{26}$

\section{F. Makna Hakekat Adat dan Tradisi dalam Islam}

Kebiasaan atau tradisi masyarakat yang dilakukan atas dasar agama adalah salah satu bentuk praktek ritual yang oleh Rippin disebut sebagai 'ritual tambahan' di luar Rukun Islam, yang dijalankan oleh kaum muslimin sebagai syi'ar agama. Dengan demikian, ritual tambahan ini bukan termasuk ibadah dalam pengertian sempit. Sebagian upacara adat tak dapat dipungkiri merupakan hasil kebudayaan yang diciptakan oleh umat muslim sendiri, sementara sebagian lain tidak jelas asalnya tapi semuanya bernuansa Islam. Aktifitas lainnya mengacu kepada upacara adat yang bukan berasal dari Islam tapi ditolelir dan dipertahankan setelah mengalami proses modifikasi Islamisasi dari bentuk aslinya. Ritual-ritual adat dalam bentuknya yang sekarang tidak membahayakan keyakinan Islam, bahkan telah digolongkan sebagai manifestasi keyakinan itu sendiri dan digunakan sebagai syi'ar Islam khas

26 Ibid, hal. 249 . 
daerah tertentu. ${ }^{27}$ Ritual adat yang termasuk jenis pertama adalah perayaan hari-hari besar Islam; sedangkan yang termasuk jenis kedua adalah syukuran/ tasyakuran dan slametan berkenaan dengan perjalanan hidup dan peringatan kelahiran seseorang. Contoh jenis yang ketiga adalah pesta musim tanam.

Berkenaan dengan nilai-nilai tradisi perayaan Maulid Nabi Muhammad, tentu saja yang harus dipahami terlebih dahulu adalah ma'na nilai berarti sesuatu yang memiliki harga, adanya manfa'at atau sesuatu yang mempunyai pengaruh. Sedangkan tradisi merupakan padanan dari kata adat, berasal dari bahasa Arab 'adat (bentuk jamak dari 'adah) yang berarti kebiasaan dan dianggap bersinonim dengan 'urf, sesuatu yang dikenal atau diterima secara umum. Adat umumnya mengacu pada konvensi yang sudah lama ada, baik yang sengaja diambil atau akibat dari penyesuaian tak sengaja terhadap keadaan, yang dipatuhi dan sangat meninggikan perbuatan atau amalan. ${ }^{28}$ Dengan pengertian ini, seekor binatang pun memiliki adatnya sendiri. ${ }^{29}$ Dahulu para ulama Sunni menganggap bahwa 'urf merupakan akar dari fiqh; namun dalam pandangan Wahabi, ‘urf, jika bertentangan dengan peraturan kaku penguasa, dianggap sebagai taghut, yaitu peri kehidupan sesat masyarakat jahiliyah. ${ }^{30}$ Adapun m(a)uludan berarti merayakan (b. Arab:mawalid=hari lahir), kelahiran Nabi Muhammad SAW pada tanggal 12 Rabi'ul Awwal (Mulud), bulan ketiga kalender Islam Jawa. Meskipun nabi diyakini wafat pada tanggal yang sama, wafatnya tidak dipentingkan dalam peringatan ini.

Sejak abad 19, khususnya karena pengaruh Van Vollenhoven, ter Haar, dan Snouck Hurgronje, adat telah digunakan oleh pemerintah kolonial Belanda sebagai istilah sah yang merujuk kepada perangkat hukum yang tersendiri, terpisah dari hukum Islam. ${ }^{31}$ Adat setempat dimasukkan dalam pokok-pokok manajemen yuridis, dan dengan jalan itulah pluralism legal diperkenalkan di Indonesia era kolonial. Dalam skema tersebut, Belanda dengan cara mengelompokkan sistem adat sebagai unit geografis kultural memilih Indonesia

27 Muhaimin AG, Islam dalam bingkai Budaya Lokal potret dari Cirebon, hal. 165.

28 Levy, R. The Social Structure of Islam, (London: Cambridge University Press) 1957, hal. 248.

29 Lihat; "Hukum Adat" dalam Ensiklopedi Islam.

30 Levy, R. (1957), hal. 248-249.

31 Lihat: "Adat" dalam Ensiklopedi Singkat Islam. 
menjadi sedikitnya 19 daerah hukum adat. ${ }^{32}$ Jadi, alih-alih hukum syari'at, hukum adat kemudian disebarluaskan sebagai upaya "menceraikan" pribumi dari Islam. Akan tetapi, penerapan hukum adat tidak juga terlalu konsisten karena pada saat yang sama, melalui UU 1854 (pasal 75 ayat 3), aturan adat yang bertentangan dengan prinsip hukum Eropa secara tegas dilarang. ${ }^{33}$

Bagi masyarakat Jawa umumnya, kata adat biasanya merujuk pada tradisi, kebiasaan, atau bentuk lain dari prilaku umum yang menjadi sifat bawaan orang yang bersangkutan (barang apa bae kang wis dilakoni deng wong akeh). Untuk menggambarkan makna ini, ilustrasi berikut mungkin dapat membantu:"Lain tempat, maka lain adat (kebiasaaan). Adat orang di sini ya seperti ini, adat orang di sana ya seperti di sana."

"Mengomentari seseorang yang mengeluh tentang anaknya yang sering menangis, seseorang akan berkata: Sudah menjadi adatnya (sifatnya), bahwa anak suka menangis (jadi jangan mengeluh atau terkejut). ${ }^{34}$

Dari presfektif masyarakat Jawa atau masyarakat Kec. Bruno bahwa adat tak lain dari tradisi. Agaknya adat dipahami sebagai fenomena alam yang kehadirannya secara umum dan inheren memberi kontribusi terhadap prilaku sosial. Beberapa bentuk adat merupakan kreasi asli daerah, sedangkan yang lain mungkin berasal dari luar. Sebagian bersifat ritual, dan sebagian lain bersifat seremonial. Kebanyakan warga masyarakat tidak tahu kapan suatu bentuk adat mulai dikerjakan atau dari mana asalnya. Dari sudut pandang agama, adat ada yang baik dan ada yang jelek; sebagian sesuai dengan syari'at dan dinyatakan dalam kaidah fiqih, sebagian lagi sesuai dengan semangat tata susila menurut Islam. Ada yang sesuai dengan Islam, dan ada pula bertentangan. ${ }^{35}$ Menurut pendapat Ellen, bahwa prasyarat untuk memahami ekspresi masyarakat lokal atas keyakinan Islamnya adalah pengenalan awal akan berbagai kultur muslim di dalam totalitas tradisi keislamannya. Muslim di seluruh dunia hidup bersama dengan aneka-ragam ceruk budaya, yang ekspresi identitasnya mengandung warna lokal yang berbeda-beda, seperti yang terwujud dalam berbagai bentuk adat. $^{36}$

${ }^{32}$ Hooker, M.B. Adat Law in Modern Indonesia, (Kuala Lumpur : Oxford University Press) 1978, hal. 16, 30.

33 Ibid, hal. 46.

34 "Ya adate ari bocah iku ya doyan nangis."

35 Muhaimin AG, Islam dalam bingkai Budaya Lokal potret dari Cirebon, hal. 168.

36 Ibid, hal. 171. 


\section{G. Tradisi Ambengan}

Tradisi Ambengan pada perayaan Hari Besar Islam terutama untuk menyambut dan memperingati Maulid Nabi Muhammad SAW dan Isra Mi'raj pada bulan Rajab, yang mana pada dua bulan tersebut masyarakat kecamatan Bruno pada umumnya dan Desa Brunorejo pada khusunya merayakan dua peristiwa besar tersebut dengan mengadakan acara peringatan dengan tradisi Ambengan.

Sebagaimana yang dikemukakan oleh salah seorang tokoh agama, dia menyatakan: "Ambengan ini merupakan sebuah tradisi pembuatan bingkisan berupa jajanan yang dikemas sedemikian rupa, diantaranya berisi nasi dan lauk pauk, ayam ingkung, telur ayam atau bebek sejumlah 10-30 butir, jajanan pasar modern maupun tradisional, pisang satu sisir atau buah-buahan yang lain seperti apel atau jeruk, juga biasanya ada yang memasukkan sandang berupa sarung bahkan ada yang menyelipkan uang jadi aksesoris bendera pada ambeng diatasnya. Ini semua sebagai refleksi dari rasa syukur dan bentuk pemberian dengan landasan sodakoh kepada saudaranya yang lain". 37

Pada mulanya, ambengan atau ambeng adalah semacam wadah seperti tenong berisi nasi beserta lauk pauk lengkap dengan "uba rampe". Namun seiring dengan perkembangan zaman, karena isinya terus bertambah bakul dan tenong ditambah dengan keranjang dari anyaman bambu atau ceting ukuran besar dari bahan plastik. Tradisi tersebut merupakan salah satu bentuk dari sekian banyak tradisi yang ada di masyarakat yang sarat nilai keagamaan dan senantiasa mengusung sikap kearifan lokal. Sebagaimana tradisi masyarakat yang muatannya budaya setempat, maka tradisi Ambengan ini juga merupakan salah satu produk budaya masyarakat pedesaan yang hingga saat ini masih berjalan dan dilestarikan, hal ini berjalan sebagai bentuk refleksi keberagamaan salah satunya rasa syukur atas hadirnya Rasulullah dalam kehidupan dengan berbagai ajarannya dengan disertai usaha untuk meneladani sikap dan prilaku Rasulullah.

Adapun berkenaan dengan tradisi peringatan Hari Besar Islam, ini sudah merupakan agenda tahunan yang diadakan Umat Islam dimana saja. Begitu pula di Desa Brunorejo beragam cara dan acara diadakan dengan tujuan untuk

37 Hasil wawancara dengan tokoh masyarakat juga tokoh agama bernama Ky Khalid pada hari Sabtu, 12 Januari 2013, jam 11.00. 
memeriahkan dan merayakan salah satu bulan yang mulia dalam Islam ini (Rabi'ul Awal/bulan Mulud). Juga pada bulan Rajab dan Sya'ban (ruwahan). Disisi lain tradisi ini merupakan pengejawantahan paham keberagamaan masyarakat, yang sarat dengan nilai-nilai sosial dan agama, sebagaimana pendapat Nasr,ia menyatakan bahwa tradisi Islam adalah perpaduan antara wahyu yang diterima Nabi dalam bentuk kitab suci dan bahwa Islam, sebagai agama, diserap sesuai dengan fitrahnya sendiri dan berhasil mencapai jati dirinya melalui peralihan dan sintesis. Tradisi Islam mencakup semua aspek religi dan percabangannya berdasarkan apa yang dicontohkan para wali. ${ }^{38}$

Lebih lanjut, Nasr berpendapat bahwa tradisi Islam layaknya sebuah pohon. Akarnya berada pada wahyu, dari akar ini tumbuhlah sekian banyak cabang dan ranting. Intinya adalah agama dan getahnya mengandung barakah, kebenaran, suci, abadi dan tak tergantikan, kearifan abadi, dan penerapannya yang terus berkesinambungan sesuai dengan kondisi zaman. Menurut definisi Nasr, tradisi Islam mencakup banyak hal, meliputi: pengetahuan, cara memandang dunia, nilai, dan perilaku yang diupayakan selalu merujuk pada kitab suci dan jiwa kitab suci. Secara teknis, cara untuk mengetahui tradisi yang dikandung oleh agama tertentu (Islam, Kristen, Hindu, Budha, dll.) adalah dengan cara mempelajari kitab sucinya masing-masing. Dengan demikian, makna leksikal "tradisi" akan dapat ditarik ke dalam perspektif Islam, dan menyatakan tradisi Islam sebagai sesuatu yang melibatkan "tradisi" di mana pemilik atau pelakunya berniat melakukan atau menyatakan dasar tindakkannya, hal itu terkait dengan, atau melahirkan, jiwa Islam dan perilaku yang diniatkan atau yang dinyatakannya itu bersumber dari dalam kitab suci. ${ }^{39}$

Dilihat dengan kacamata agama peringatan Hari Besar Islam terutama Maulid Nabi Muhammad SAW dan Rajaban atau Isra' Mi'raj (Rojabiyah) juga ruwahan (majmukan) dimana kental di dalamnya ada tradisi Ambengan merupakan suatu fenomena budaya yang dibungkus nilai keagamaan menghadirkan nuansa nilai-nilai kegamaan yang cukup kental, disini terbangun sillaturrahmi antar anggota masyarakat secara intens, secara bergiliran setiap pedukuhan mengadakan acara peringatan Maulid Nabi Muhammad dengan mengundang beberapa warga dari pedukuhan lain masih dalam satu desa,

${ }_{38}$ Muhaimin AG, Islam dalam bingkai Budaya Lokal potret dari Cirebon, hal. 13

39 SH. Nasr, Islamic Life and Thought, (Boston :George Allen \& Unwin), 1981 
bahkan juga dengan mengundang beberapa warga dari desa tetangga. Biasanya warga yang diundang setelah acara akan diberi oleh-oleh berupa "ambeng", atau istilah lain jajanan yang ditempatkan pada wadah "ceting", isinya ayam ingkung (ayam yang dimasak utuh tanpa dipotong-potong, bisa berupa ayam kampung atau boyler, sikepala ayam tersebut diletakkan diantara dua sayapnya, kemudian kakinya ditekuk), ${ }^{40}$ nasi, telur, lauk-pauk lainnya, dan panganan berupa hasil bumi atau jajanan warung, bahkan terkadang uang atau sandangan berupa sarung atau baju muslim (koko).

Namun sebelumnya ada kegiatan saling berkirim makanan "munjungi" antar keluarga ataupun kepada seseorang yang dianggap berperan dalam kehidupannya, seperti para kiyai, ustadz, atau guru ngaji/guru spiritual. Hal ini dilakukan sebagai sarana silaturrahmi dan bagian dari bentuk sodaqoh berupa makanan dalam hal ini berisi nasi beserta lauk-pauk (ayam, sayuran, telur). Maka nuansa saling memberi dan menerima itu jelas nampak dalam tradisi peringatan Maulid Nabi Muhammad SAW maupun Rajaban serta ruwahan atau majmukan di masyarakat Kec. Bruno Khususnya Desa Brunorejo, dimana penulis tinggal. Disini nampak bergabungnya dimensi spiritual maupun material dengan ciri adanya pergerakan sosial-ekonomi yang cukup kental, dimana warga masyarakat dengan sukarela belanja keperluan perayaan dengan tidak sedikit mengeluarkan biaya.

Dalam Konteks kehidupan sosial, nilai-nilai tradisi diatas merupakan sinergi dua dimensi seorang muslim pada sisi sosial dan spiritual. Dimensi terpenting dari konteks keberislaman adalah setaranya dua sisi pemilikan kehidupan mental-spiritualitas (bernuansa transenden) dan fisik-materia (bersifat keduniaan) yang keduanya harus diraih oleh setiap muslim. Ditegaskan dalam konsepsi Islam, sikap laku yang lebih mengutamakan urusan keduniaan-yang biasanya diwujudkan dalam tradisi-tradisi kemanusiaan: meraup semua apa yang dipandang dapat menyenangkan dan memenuhi semua hajat hidup diri sendiri dan keluarga-ternyata merupakan kesalahpahaman. Karena dimensi sosial senyatanya menduduki porsi yang sama untuk dikedepankan oleh setiap individu. ${ }^{41}$

\footnotetext{
40 Sebagaimana dijelaskan oleh H. Dulbahri (jama'ah)

41 A.Wahab Suneth \& Syarifuddin Djosan, Problematika Dakwah Dalam Era Indonesia Baru, (Jakarta:Bina Rena Pariwara, 2000), hal.10
} 
Nilai-nilai tradisi budaya yang mengandung muatan keagamaan ini, tentu saja masyarakat yang melaksanakannya menyebut dengan ibadah, dengan kata lain tradisi Maulid Nabi Muhammad merupakan salah satu cara "nguringuri agama" (menghidup-hidupkan nilai agama) dalam kehidupan. Dan yang lebih penting tradisi peringatan Maulid Nabi dengan berbagai ragam kegiatan dan acara ini, bagian dari perwujudan rasa cinta terhadap "sang kekasih" yaitu Junjungan Nabi Besar Muhammad SAW, dengan berupaya memahami semua ajarannya dan melaksanakannya dalam kehidupan, sebagaimana ditegaskan dalam sabdanya, yang artinya :"Barangsiapa yang menghidup-hidupkan sunahku, maka dia sudah mencintaiku, dan barangsiapa yang mencintaiku, maka dia bersamaku di surga".

\section{H. Penyelenggaraan Tradisi Ambengan Pada Hari Besar Islam}

Sebelum mendeskripsikan lebih jauh tentang penyelenggaraan Tradisi Ambengan, penulis terlebih dahulu ingin menjelaskan hal yang berkaitan dengan arti dan makna Ambeng. Masyarakat desa Brunorejo pada umumnya sudah memiliki pemahaman yang sama tentang arti Ambeng ataupun Ambengan yaitu: wadah tenong berisi nasi beserta lauk pauk lengkap dengan "uba rampe". Sebagaimana yang dikatakan oleh Ky. Khalid (seorang tokoh masyarakat) bahwa Ambeng itu merupakan "berkat" atau bingkisan yang berisi nasi dan lauk pauk serta jajanan yang ditata dalam sebuah tempat.bn Namun seiring dengan perkembangan zaman, karena isinya terus bertambah bakul dan tenong ditambah dengan keranjang dari anyaman bambu atau ceting ukuran besar dari bahan plastik. Tradisi tersebut merupakan salah satu bentuk dari sekian banyak tradisi yang ada di masyarakat yang sarat nilai keagamaan dan senantiasa mengusung sikap kearifan lokal.

Sebagaimana tradisi masyarakat yang muatannya budaya setempat, maka tradisi Ambengan ini juga merupakan salah satu produk budaya masyarakat pedesaan yang hingga saat ini masih berjalan dan dilestarikan, hal ini berjalan sebagai bentuk refleksi keberagamaan salah satunya rasa syukur atas hadirnya Rasulullah dalam kehidupan dengan berbagai ajarannya dengan disertai usaha untuk meneladani sikap dan prilaku Rasulullah. Adapun berkenaan dengan tradisi peringatan Hari Besar Islam ini sudah merupakan agenda tahunan yang diadakan Umat Islam dimana saja. Beragam cara dan acara diadakan dengan 
tujuan untuk memeriahkan dan merayakan salah satu bulan yang mulia dalam Islam ini (Rabi'ul Awal/bulan Mulud). Disisi lain tradisi ini merupakan pengejawantahan paham keberagamaan masyarakat, yang sarat dengan nilainilai sosial dan agama, sebagaimana pendapat Nasr, ia menyatakan bahwa tradisi Islam adalah perpaduan antara wahyu yang diterima Nabi dalam bentuk Kitab Suci dan bahwa Islam, sebagai agama, diserap sesuai dengan fitrahnya sendiri dan berhasil mencapai jati dirinya melalui peralihan dan sintesis. Tradisi Islam mencakup semua aspek religi dan percabangannya berdasarkan apa yang dicontohkan para wali. ${ }^{42}$

Lebih lanjut, Nasr berpendapat bahwa tradisi Islam layaknya sebuah pohon. Akarnya berada pada wahyu, dari akar ini tumbuhlah sekian banyak cabang dan ranting. Intinya adalah agama dan getahnya mengandung barakah, kebenaran, suci, abadi dan tak tergantikan, kearifan abadi, dan penerapannya yang terus berkesinambungan sesuai dengan kondisi zaman. Menurut definisi Nasr, tradisi Islam mencakup banyak hal, meliputi: pengetahuan, cara memandang dunia, nilai, dan perilaku yang diupayakan selalu merujuk pada kitab suci dan jiwa kitab suci. Secara teknis, cara untuk mengetahui tradisi yang dikandung oleh agama tertentu (Islam, Kristen, Hindu, Budha, dll.) adalah dengan cara mempelajari kitab sucinya masing-masing. Dengan demikian, makna leksikal "tradisi" akan dapat ditarik ke dalam perspektif Islam, dan menyatakan tradisi Islam sebagai sesuatu yang melibatkan "tradisi" di mana pemilik atau pelakunya berniat melakukan atau menyatakan dasar tindakkannya, hal itu terkait dengan, atau melahirkan, jiwa Islam dan perilaku yang diniatkan atau yang dinyatakannya itu bersumber dari dalam kitab suci. ${ }^{43}$

Dilihat dengan kacamata agama peringatan Hari Besar Islam terutama Maulid Nabi Muhammad SAW dan Rajaban dimana kental di dalamnya ada tradisi Ambengan merupakan suatu fenomena budaya yang dibungkus nilai keagamaan menghadirkan nuansa nilai-nilai kegamaan yang cukup kental, disini terbangun sillaturrahmi antar anggota masyarakat secara intens, secara bergiliran setiap pedukuhan mengadakan acara peringatan Maulid Nabi Muhammad dengan mengundang beberapa warga dari pedukuhan lain masih

${ }^{42}$ Muhaimin AG, Islam dalam bingkai Budaya Lokal potret dari Cirebon, hal. 13

43 SH. Nasr, Islamic Life and Thought, (Boston:George Allen \& Unwin, 1981) 
dalam satu desa, bahkan juga dengan mengundang beberapa warga dari desa tetangga. Biasanya warga yang diundang setelah acara akan diberi oleh-oleh berupa "ambeng", atau istilah lain jajanan yang ditempatkan pada wadah "ceting", isinya ayam ingkung, nasi, telur, lauk-pauk lainnya, dan panganan berupa hasil bumi atau jajanan warung, bahkan terkadang uang atau sandangan berupa sarung atau baju muslim (koko). Namun sebelumnya ada kegiatan saling berkirim makanan "munjungi" antar keluarga ataupun kepada seseorang yang dianggap berperan dalam kehidupannya, seperti para kiyai, ustadz, atau guru ngaji/guru spiritual. Hal ini dilakukan sebagai sarana silaturrahmi dan bagian dari bentuk sodaqoh berupa makanan. Maka nuansa saling memberi dan menerima itu jelas nampak dalam tradisi peringatan Maulid Nabi Muhammad maupun Rajaban serta Ruwahan atau majmukan di masyarakat Kec. Bruno Khususnya Desa Brunorejo. Disini nampak bergabungnya dimensi spiritual maupun material dengan ciri adanya pergerakan sosial-ekonomi yang cukup kental, dimana warga masyarakat dengan sukarela belanja keperluan peringatan dengan tidak sedikit mengeluarkan biaya.

Ambeng serta isinya merupakan simbol yang sarat arti, bagi warga desa Brunorejo yang merupakan bagian dari masyarakat Jawa segala sesuatu sering disampaikan lewat simbol. Sebagaimana yang dikatakan Budiono Hadi Sutrisno, tentang sistem simbol yang digunakan sebagai media untuk menyampaikan pesan. Kadang-kadang, simbol tersebut berupa sesuatu yang rumit, sehingga hanya manusia yang memiliki pengetahuan linuwih, yang akan mampu memahami segala bentuk dan tujuan dari simbol-simbol itu. Pepatah Jawa Klasik mengatakan "wong Jawa iku nggoning semu, sinamun ing samudana, sesadone ingadu manis. Maksudnya, orang Jawa itu tempatnya segala simbol. Segala sesuatunya disamarkan secara semu dengan maksud agar tampak indah dan manis. ${ }^{44}$

Sebagaimana makna simbol yang ada di dalam tradisi Ambengan, menurut H. Abdul Bahri (warga masyarakat), yaitu:

1. Telur melambangkan kekuatan

2. Kelapa melambangkan ketahanan fisik

3. Ingkung melambangkan embrio

4. Jajan pasar melambangkan kekayaan

${ }^{44}$ Budiono Hadi Sutrisno, Kitab Seks Leluhur Jawa, (Yogyakarta: Eule Book, 2010), hal.13 
5. Pisang raja melambangkan budi luhur atau derajat mulia

6. Gula jawa melambangkan kemanisan hidup

7. Sega gudangan melambangkan kesegaran jasmani rohani

8. Dawet melambangkan kelancaran usaha hidup

Simbol-simbol yang ada dalam Ambeng seakan memberikan gambaran seutuhnya bahwa manusia senantiasa berharap kepada Allah sang pencipta, untuk memberikan kehidupan yang baik dengan mengedepankan rasa syukur atas segala apa yang telah dianugrahkan di dalam kehidupannya, seraya terusmenerus memunculkan rasa optimisme menghadapi segala tantangan maupun rintangan dalam upaya mencapai cita-cita kehidupan. Jadi simbol-simbol tersebut cukup memberi arti bagi manusia, bahwa antara harapan (cita-cita), usaha dan do'a harus bersamaan diwujudkan dalam arti sesungguhnya.

\section{Nilai-nilai Pendidikan Islam pada tradisi Ambengan}

Tradisi Ambengan pada peringatan Hari-hari Besar Islam memberikan pengaruh secara keagamaan di dalam masyarakat, khususnya warga desa Brunorejo. Hal tersebut berkaitan erat dengan nilai-nilai yang terkandung dalam tradisi tersebut, dalam hal ini pendidikan Islam. Oleh karena itu dapat dijelaskan dengan menganalisa berbagai rangkaian kegiatan dan dinamika sosial keagamaan yang sudah berjalan di masyarakat. Mulai dari penetapan waktu dan tempat pelaksanaan peringatan HBI, adanya kepanitiaan kegiatan, pengerahan masa, konsolidasi warga, serta komunikasi yang intensif antara pengurus masjid, tokoh masyarakat, tokoh agama, unsur pemerintahan, panitia dan juga warga. Antusiasme masyarakat diwujudkan dengan ragam kegiatan sosial keagamaan yang diadakan di masing-masing lingkungan. Kondisi keagamaan yang kondusif dan semaraknya kegiatan di lingkungan masyarakat merupakan indikasi semakin bertambahnya kesadaran dalam keberagamaan. Tumbuh kembangnya secara merata kelompok-kelompok pengajian di setiap lingkungan, baik pada kalangan anak-anak, remaja hingga orang dewasa. Sifat pengajian harian seperti pengajian anak-anak (membaca al-Qur'an atau iqra' yang dilaksanakan ba' da subuh, ba'da asar dan ba' da Maghrib bertempat di masjid, mushola atau surau atau bahkan di rumah guru ngaji), mingguan, bulanan, selapanan dan tahunan (haulan, halal bihalal, walimatul safar). Nama pengajian juga beragam, ada "tahlilan", "malam jum'atan", "reboan", "qur'anan", "yasinan" dll. 
Hal ini merupakan aktualisasi dari nilai-nilai pendidikan yang bisa diserap masayarakat melalui tradisi Ambengan pada peringatan HBI. Adanya penyampaian ceramah keagamaan dalam kegiatan peringatan merupakan salah satu alasan penting masyarakat mendapatkan pencerahan dalam hal spiritual, menurut pengamatan penulis materi-materi ceramah yang disampaikan biasanya berkaitan dengan nilai ketaqwaan dalam ibadah : masalah aqidah (keimanan), akhlakul karimah, syari'ah, fiqh maupun tentang tamadun (kesejarahan Islam).Maka tradisi yang selama ini dilestarikan dan dijaga sebenarnya banyak mengandung makna terutama nilai pendidikan Islam dalam aspek keimanan, akhlak, syari'ah dan mu'amalah.

\section{Pendidikan Keimanan}

Agama Islam bersumber dari al-Qur'an yang memuat wahyu Allah dan al-Hadits yang memuat sunah Rasulullah. Komponen utama agama Islam atau unsur utama ajaran agama Islam (akidah, syari'an akhlak) dikembangkan dengan rakyu atau akal pikiran manusia yang memenuhi syarat untuk mengembangkannya. Yang dikembangkan adalah ajaran agama yang terdapat dalam al-Qur'an dan al-Hadits. Dengan kata lain, yang dikembangkan lebih lanjut supaya dapat dipahami manusia adalah wahyu Allah dan sunnah Rasul yang merupakan agama (Islam) itu. ${ }^{45}$ Itu semua merupakan dasar pokok dalam upaya untuk memahami tentang keimanan dan keislaman sebagai upaya meraih derajat ketakwaan di sisi Allah.Diantara nilai-nilai pendidikan keimanan yaitu:

Pertama, Aqidah, yang dimaksud dengan aqidah dalam bahasa Arab (bahasa Indonesia akidah, menurut etimologi, adalah ikatan, sangkutan. Disebut demikian, karena ia mengikat dan menjadi sangkutan atau gantungan segala sesuatu. Dalam pengertian teknis artinya adalah iman atau keyakinan. Akidah Islam (aqidah islamiyah), karena itu, ditautkan dengan rukun iman yang menjadi asas seluruh ajaran Islam. Kedudukannya sangat sentral dan fundamental, karena, seperti telah disebutkan di atas, menjadi asas dan sekaligus sangkutan atau gantungan segala sesuatu dalam Islam. Juga menjadi titik tolak kegiatan seorang muslim. ${ }^{46}$

45 Muhammad Daud Ali, Pendidikan Agama Islam, (Jakarta: Raja Grafindo Persada, 2003), hal. 89.

46 Ibid, hal. 199 
Akidah Islam berawal dari keyakinan kepada Zat Mutlak Yang Maha Esa yang disebut Allah. Allah Maha Esa dalam zat, sifat, perbuatan dan wujud-Nya. Kemaha-Esaan Allah dalam zat, sifat, perbuatan dan wujud-Nya itu disebut tauhid. Tauhid menjadi inti rukun iman dan prima causa seluruh keyakinan Islam. Rukun Iman adalah pokok-pokok keyakinan yang merupakan asas seluruh ajaran Islam, jumlahnya ada enam ; dimulai dari 1) keyakinan kepada Allah, Tuhan Yang Maha Esa, 2) keyakinan kepada Malaikat-malaikat, 3) keyakinan kepada Kitab-kitab suci, 4) keyakinan kepada Nabi dan Rasul Allah, 5) keyakinan akan adanya Hari Akhir, dan 6) keyakinan pada Kada dan Kadar Allah. Pokok-pokok keyakinan atau Rukun Iman ini merupakan akidah Islam. ${ }^{47}$

Kedua, Syari'at. Makna syari'at adalah jalan ke sumber (mata) air. Dulu (di Arab) orang mempergunakan kata itu untuk sebutan jalan setapak menuju ke mata (sumber) air yang diperlukan manusia (untuk minum dan membersihkan diri). Perkataan syari'at (syari'ah) dalam bahasa Arab berasal dari kata syari', secara harfiah berarti jalan yang harus dilalui oleh setiap muslim. Selain akidah (pegangan hidup), akhlak (sikap hidup), syari' at (jalan hidup) adalah salah satu bagian agama Islam. Menurut ajaran Islam, syari'at ditetapkan Allah menjadi patokan hidup setiap muslim. Sebagai jalan hidup, ia merupakan way of lifeumat Islam. ${ }^{48}$

Menurut Mohammad Idrus as Syafi'i (Imam Syafi'i) dalam kitab beliau ar Risalah, syari'at adalah peraturan-peraturan lahir yang bersumber dari wahyu dan kesimpulan -kesimpulan yang berasal dari wahyu itu mengenai tingkah laku manusia. Dilihat dari segi ilmu hukum, syari'at adalah norma hukum dasar yang diwahyukan Allah, yang wajib diikuti oleh orang Islam, baik dalam berhubungan dengan Allah maupun berhubungan dengan sesama manusia dan benda dalam masyarakat. Norma hukum dasar ini dijelaskan atau dirinci lebih lanjut oleh Nabi Muhammad SAW sebagai Rasul-Nya. Karena itu, syari'at terdapat di dalam al-Qur'an dan kitab-kitab Hadits. Menurut sunnah Nabi Muhammad SAW, seperti telah disebut di muka, umat Islam tidak akan pernah keliru atau sesat dalam perjalanan hidupnya di dunia ini, selama mereka berpegang teguh kepada al-Qur'an dan Sunnah. ${ }^{4}$

\footnotetext{
47 Ibid, hal. 201

48 Ibid, hal. 235

49 Ibid, hal. 236
} 
Karena norma-norma hukum dasar yang terdapat di dalam al-Qur'an itu masih ada yang bersifat umum, perlu dirumuskan lebih lanjut setelah Nabi Muhammad SAW wafat. Perumusan norma-norma hukum dasar ke dalam kaidah-kaidah yang lebih konkret, memerlukan cara-cara tertentu. Muncullah ilmu pengetahuan yang khusus menguraikan syari'at. Dalam kepustakaan hukum Islam ilmu tersebut dinamakan ilmu fikih yang diterjemahkan ke dalam bahasa Indonesia dengan hukum ilmu fikih Islam. Orang paham tentang ilmu fikih disebut fakih ataufukaha (jamak). Artinya ahli hukum (fikih) Islam.

Dalam bahasa Arab, fikih artinya paham atau pengertian. Kalau dihubungkan dengan perkataan ilmu di atas, ilmu fikih adalah ilmu yang bertugas memahami dan menguraikan norma-norma hukum dasar yang terdapat di dalam al-Qur'an dan Sunnah Nabi Muhammad SAW. Dengan kata lain, ilmu fikih adalah ilmu yang berusaha memahami hukum-hukum dasar yang tersapat di dalam alQur'an dan kitab-kitab Hadits. Pemahaman itu dituangkan ke dalam kitabkitab fikih dan disebut hukum fikih.

Ketiga, Akhlak. Perkataan akhlak berasal dari bahasa Arab akhlaq, bentk jamak kata khuluq atau al-khulq, yang secara etimologis antara lain berarti budi pekereti, perangai, tingkah laku atau tabi'at. ${ }^{50}$ Dalam kepustakaan, akhlak diartikan juga sikap yang melahirkan perbuatan (perilaku, tingkah laku) mungkin baik, mungkin buruk.

Akhlak menempati posisi yang sangat penting dalam Islam. Ia dengan takwa, merupakan 'buah' pohon Islam yang berakarkan akidah, bercabang dan berdaun syari'ah. Pentingnya kedudukan akhlak, dapat dilihat dari berbagai sunnah qauliyah (sunnah dalam bentuk perkataan) Rasulullah. Diantaranya adalah, "Sesungguhnya aku diutus untuk menyempurnakan akhlak" (Hadis Rawahu Ahmad);"Mukmin yang paling sempurna imannya adalah yang paling baik akhlaknya" (HR. Tarmizi). Dan akhlak Nabi Muhammad SAW, yang diutus menyempurnakan akhlak manusia iru, disebut akhlak Islam atau akhlak Islami, karena bersumber dari wahyu Allah yang itu terdapat dalam al-Qur'an yang menjadi sumber utama agama dan ajaran Islam. Maka seringkali para ulama menyatakan ingin mengetahui dan memahami akhlak Rasulullah maka pahami dan pelajari al-Qur'an. Jadi al-Qur'an sepenuhnya bisa menjelaskan bagaimana

50 RachmatDjatnika, Sistem Etika Islami “Akhlak Mulia” (Jakarta: Pustaka Panjimas, 1996), hal 25 
Rasulullah selama hidupnya bersikap, bertindak, berucap. Bagaimana cara Rasul berhubungan dengan Allah maupun dengan manusia juga dengan alam lingkungan.

\section{Pendidikan Sosial Keagamaan}

Pendidikan dalam arti luas bermakna merubah dan memindahkan nilai kebudayaan kepada setiap individu dalam masyarakat. ${ }^{51}$ Sedangkan menurut H.M Arifin hakekat pendidikan adalah usaha orang dewasa secara sadar terhadap anak didik untuk membimbing dan mengembangkan kepribadian serta kemampuan dasar anak didik baik dalam pendidikan formal, non formal maupun informal. ${ }^{52}$ Pendidikan dapat diartikan sebagai usaha manusia untuk membina kepribadian sesuai dengan nilai-nilai di dalam masyarakat dan kebudayaan. Demikian halnya dengan pendidikan Islam mempunyai fungsi dan peran yang lebih besar dalam membentuk akhlak kepribadian masyarakat.

Berbeda dengan Pendidikan Agama Islam yang dalam penanaman nilai menggunakan beberapa pendekatan, yaitu melalui : (1) Pendekatan penanaman nilai atau incucation approach, (2) Pendekatan perkembangan moral kognitif atau cognitive moral development approach, (3) Pendekatan analisis nilai atau beluaes analysis approach, (4) Pendekatan klarifikasi nilai atau values clarification approach, dan (5) Pendekatan pembelajaran berbuat (action learning approach).

Adapun pengertian dan tujuan dari pendidikan Islam yang telah dikemukakan oleh beberapa pakar pendidikan antara lain pendapat dari Zuhairini yang menyatakan bahwa pendidikan Islam adalah usaha yang diarahkan kepada pembentukan kepribadian anak sesuai dengan ajaran Islam atau segala upaya dengan ajaran Islam, memikirkan, memutuskan dan berbuat berdasarkan nilai-nilai. ${ }^{53}$

Lain halnya dengan Zakiyah Darajat, yang mengkonsepsikan tujuan pendidikan adalah suatu proses untuk membentuk kepribadian peserta didik menjadi insan kamil. Artinya peserta didik yang utuh baik secara jasmani maupun rohani serta dapat berkembang secara wajar dan normal. ${ }^{54}$ Pada

51 Koentjaraningrat, Kebudayaan Jawa, (Jakarta:Balai Pustaka, 1994), hal. 324.

${ }^{52}$ H.M. Arifin, Hubungan Timbal Balik Pendidikan Agama di Lingkungan Sekolah dan Keluarga, (Jakarta: Bulan Bintang, 1987), hal. 12.

53 Zuhairini, Filsafat Pendidikan Islam, (Jakarta: Bumi Aksara, 1995), hal. 152.

54 Zakiyah Darajat, Ilmu Pendidikan Islam, (Jakarta: Bumi Aksara, 2000), hal. 29-30. 
prinsipnya segala proses yang mengarah kepada pembentukan jiwa, karakter kepribadian sesorang sepanjang sesuai dengan ajaran agama dan tidak ada penyimpangan, maka sudah bisa dikatakan proses tersebut mengandung nilainilai pendidikan.

Sedangkan menurut Kohstan dan Guning sebagaimana dikutip Muhaimain dan Abdul Majid, tujuan Pendidikan Islam mengupayakan bentuk manusia kamil, yaitu manusia yang dapat menunjukkan keselarasan dan keharmonisan antara jasmani rohani, baik dalam segi kejiwaan, kehidupan individu, maupun untuk kehidupan bersama yang menjadikan inti hakekat manusia. ${ }^{55}$ Menurut Ali Yafie, konsep insan kamil lebih cenderung diartikan sebagai manusia yang memiliki keseimbangan mental, yang dapat memadukan kehidupan dan kehidupan sosialnya sebagai warga masyarakat. Manusia semacam ini merupakan hasil kajian terhadap Al-Qur'an, yaitu manusia yang memiliki kesadaran bahwa kehadirannya di muka bumi ini tidaklah sendirian. Dia bersama dengan sesama manusia, makhluk dan benda liannya yang juga samasama ciptaan Tuhan. ${ }^{56}$

Di lain pihak, Hasan Langgulung berpendapat bahwa tujuan Pendidikan Islam yang akan dicapai adalah mengembangkan fitrah (potensi) manusia, baik ruh, fisik, kemauan, dan akalnya secara dinamis, sehingga akan terbentuk pribadi utuh dan dapat mendukung bagi berfungsinya sebagai khalifah di bumi. ${ }^{57}$

Di samping itu, tujuan pendidikan Islam adalah untuk membimbing dan mengarahkan manusia agar mampu mengemban amanah dari Allah, yaitu menjalankan tugas-tugasnya di bumi, baik sebagai 'abdullah (hamba Allah yang harus tunduk dan taat pada segala aturan dan hendaknya serta mengabdi hanya kepada dirinya) maupun sebagai khalifah Allah di bumi, yang menyangkut pelaksanaan tugas khalifah terhadap diri sendiri, dalam keluarga, dalam masyarakat, dan tugas kekhalifahan terhadap alam. Tugas khalifah terhadap diri sendiri menyangkut tugas menuntut ilmu pengetahuan,

55 Muhaimin dan Abdul Majid, Pemikiran Pendidikan Islam Kajian Filosofik dan Kerangka Dasar Oprasionalisasinya, (Bandung: TrigendaKarya, 1993), hal. 157.

56 Ali Yafie, Teologi Sosial Telaah Kritis Persoalan Agama dan Kemanusiaan. (Yogyakarta: LKPSM, 1997), hal. 156.

57 Hasan Langgulung, Pendidikan Islam Menghadapi Abad ke-21, (Jakarta: Pustaka AlHusna, 1998), hal. 67. 
menjaga diri dari sesuatu yang dapat menimbulkan bahaya kesengsaraan, misalnya menjaga kesehatan fisiknya, memakan makanan yang halal, dan terakhir adalah menghiasai diri dengan akhlak yang mulia. Tugas kekhalifahan dalam masyarakat meliputi mewujudkan persatuan dan kesatuan umat, tolongmenolong dalam kebaikan dan ketaqwaan, menegakkan keadilaln dalam masyarkat dan sebagainya.

Tugas kekhalifahan terhadap alam meliputi:

1. Membudayakan alam. Artinya alam yang ada ini agar dibudayakan sehingga menghasilkan karya-karya yang bermanfaat bagi kemaslahatan umat.

2. Mengalamkan budaya, artinya budaya atau hasil karya manusia harus disesuaikan dengan kondisi alam dan lingkungan hidup, agar tidak membahayakan bagi sesama manusia dan lingkungan sekitarnya.

3. Mengislamkan budaya. Artinya dalam berbudaya harus tetap komitmen dengan nilai-nilai Islam yang rahmatan lil 'alamin sehingga berbudaya berarti mengerahkan segenap tenaga, cipta, rasa, dan karsa serta bakat manusia untuk mencari dan menemukan kebenaran ajaran Islam dan kebenaran ayat-ayat serta keagungan dan kebesaran Ilahi. ${ }^{58}$

Maka dari itu sudah menjadi tugas pendidikan Islam untuk mewariskan nilai-nilai budaya Islami, karena kebudayaan Islam akan mati bila nilai-nilai dan norma-norma tidak berfungsi serta belum sempat diwariskan kepada generasi penerusnya. ${ }^{59}$

\section{J. Penutup}

Nilai-nilai Pendidikan Islam yang terdapat dalam tradisi Ambengan ini diantaranya adalah: nilai pendidikan keimanan, nilai pendidikan akhlak dan nilai pendidikan sosial. Nilai-nilai pendidikan ini terdapat dalam simbol-simbol yang termuat dalam perlengkapan pelaksanaan tradisi Ambengan maupun dalam prosesinya. Nilai-nilai pendidikan tersebut memiliki makna yang dalam sebagai kearifan lokal yang diharap mampu mereduksi radikalisme yang masuk

58 Muhaimin, et.al. Paradigma Pendidikan Islam Upaya Mengefektifkan Pendidikan Agama Islam di Sekolah, (Bandung: Remaja Rosda Karya, 2004), hal. 23-24..

59 Muhaimin dan Abdul Majid, Pemikiran Pendidikan Islam..., hal. 143. 
dalam kehidupan masyarakat saat ini. Sebagai hasil budaya yang berdasarkan agama, maka diharapkan mampu untuk terus dikembangkan sebagai media internalisasi nilai-nilai pendidikan di masyarakat. Sehingga akan mampu diserap lalu diterjemahkan secara utuh dalam kehidupan bermasyarakat.

Mekanisme Tradisi Ambengan yang dilaksanakan masyarakat desa Brunorejo pada peringatan HBI (Hari Besar Islam), peringatan Maulid Nabi Muhammad SAW (muludan pada bulan Rabi'ul Awal), peringatan Isra Mi'raj (Rajaban pada bulan Rajab), peringatan Ruwahan (Majmukan pada bulan Sya'ban). Yang kesemuanya dilaksanakan pada masing-masing tempat ibadah (masjid/mushola) di setiap pedukuhan yang ada di desa Brunorejo Kec. Bruno Kab. Purworejo. Tradisi Ambengan ini memiliki tujuan untuk mengungkapkan rasa syukur kepada Allah, dan merupakan manisfestasi rasa cinta atas hadirnya Rasulullah yang telah membawa ajaran Islam dalam kehidupan mereka.

Pengaruh Tradisi Ambengan sebagai bagian dari media untuk penyampaian nilai-nilai pendidikan Islam, memberikan dampak besar dalam kehidupan masyarakat baik dalam bidang teologhis (agama), bidang sosial, bidang budaya, bidang ekonomi dan bidang politik. Dan yang jauh lebih penting bahwa Tradisi Ambengan ini merupakan sebuah institusi atau lembaga pendidikan yang mampu bertransformasi dalam mencapai tujuan pendidikan di masyarakat dengan mengsinergikan nilai-nilai budaya (kearifan lokal) dengan nilai luhur ajaran Islam sehingga mampu memberikan warna dan mendesakkan Islam sebagai nilai kehidupan masyarakat.

\section{DAFTAR PUSTAKA}

A.Wahab Suneth \& Syarifuddin Djosan. 2000. Problematika Dakwah Dalam Era Indonesia Baru. Jakarta: Bina Rena Pariwara.

Abu Bakar, Usman dan Surohim. 2005. Fungsi Ganda Lembaga Pendidikan Islam (Respon Kreatif terhadap Undang-undag Pendidikan Nasional). Yogyakarta: Safira Insania Press, Cet. I

Adnan K.H.M. 1969. Peringatan Hari-hari Besar Islam. Sala: A.B. Siti Syamsiyah Ali, Daud. 2003. Muhammad Pendidikan Agama Islam. Jakarta: Raja Grafindo Persada.

Al-Iqtishad fi al-I'tiqad, Kairo: Maktabah Shubaih

Amir Feisal, Jusuf. 1995. Reorientasi Pendidikan Islam. Jakarta: Gema Insani Pres, cet. I 
Arwani.2008. Memaknai Tradisi Mauludan di Krajan Purworejo dimuat dalam buku "Agama dan Kearifan Lokal Dalam Tantangan Global". Yogyakarta: Sekolah Pascasarjana UGM cet. I

Barth, Fredrik.1993. Balinese Worlds, Chicago: The Universitiy of Chicago Press.

Berger, Peter L. 1994. Langit Suci, LP3ES, cet.II.

Buseri, Kamrani. 2003. Antologi Pendidikan Islam dan Da'wah. Yogyakarta: UII Press.

Dahlan,Aminah Abdullah. 1988. Hadits Arba'in Annawawiyyah. Bandung: AlMa'arif.

Darajat, Zakiyah. 2000. Ilmu Pendidikan Islam. Jakarta: Bumi Aksara.

Depdikbud,1990. Kamus Besar Bahasa Indonesia. Jakarta: Balai Pustaka.

Fadjar, Malik H. A.1998. Visi Pembaruan Pendidikan Islam. Jakarta: LP3NI.

Funk and Wagnalls, 1984. Standard Desk Dictionary. Cambridge: Harper and Row.

Hadi, Sutrisno. 2004. Metodologi Research.Yogyakarta: Andi Offset, jilid 2.

Hooker, M.B. 1978. Adat Law in Modern Indonesia. Kuala Lumpur: Oxford University Press

Hudayat, Taufiq. 1996. Memeluk Islam sebagai Kesadaran Hidup, dalam kumpulan tulisan Ruh Islam dalam Budaya Bangsa; Agama dan Problema Masa Kinil. Jakarta: Yayasan Festival Istiqlal.

Imarah, Muhammad. 1999.Islam dan Keamanan Sosial. Jakarta: Gema Insan Press

Karim, Muhith,. A. dkk. 2002. Peta Kerukunan Jawa Timur (Umat Beragama di Indonesia). Jakarta : Bagian Proyek Peningkatan Pengkajian Kerukunan Hidup Umat Beragama Pusat Litbang Kehidupan Beragama Depag RI.

Langgulung, Hasan. 1998. Pendidikan Islam Menghadapi Abad ke-21. Jakarta: Pustaka Al-Husna.

Moertjipto dkk. 1997.Wujud, Arti, Dan Fungsi Puncak-puncak Kebudayaan Lama dan Asli Bagi Masyarakat Pendukungnya Di Daerah Istimewa Yogyakarta. Yogyakarta: Departemen Pendidikan dan Kebudayaan.

Muhaimin AG, 2002. Islam dalam bingkai Budaya Lokal potret dari Cirebon. Jakarta: PT. Logos Wacana Ilmu. 
Muhaimin dan Abdul Majid. 1993. Pemikiran Pendidikan Islam Kajian Filosofik dan Kerangka Dasar Oprasionalisasinya. Bandung: Trigenda Karya

Muhaimin, et.al. 2004.Paradigma Pendidikan Islam Upaya Mengefektifkan Pendidikan Agama Islam di Sekolah. Bandung: Remaja Rosda Karya.

Muhammad, Afif. 1998. Islam "Mazhab Masa Depan", menuju Islam non Sektarian. Bandung: Pustaka Hidayah

Murwanto. 2006.Nyadran dan kearifan Budaya, Kedaulatan Rakyat. edisi Selasa, 12 September

Nawawi, Haedar. 1995. Metode Penelitian Bidang Sosial. Yogyakarta: Gajah Mada University Press.

Nizar, Samsul. 2002. Filsafat Pendidikan Islam, Pendidikan Historis, teoritis dan praktis. Jakarta: Ciputut Pers, cetakan I

O Kattsof, Louis. 1993. Pengantar Filsafat, terj. Soejono Soemargono. Yogyakarta: Tiara Wacana

Rais, Amien. tt. Tauhid Sosial, http:/ / www.oocities.

S.Purnomo. 1995. "Nilai dan Norma Masyarakat". Jurnal Filsafat, No. 23 November

Sanaky, Hujair AH. 2003. Paradigma Pendidikan Islam, membangun masyarakat Madani Indonesi. Yogyakarta: Insania Press. Cet. I

SH. Nasr. 1983.Islamic Life and Thought,Boston: George Allen \& Unwin Soekamto, Soerjono.1983.Kamus Sosiologi. Jakarta: Rajawali

Sugiyono.2006. Metode Penelitian Pendidikan, Pendekatan Kuantitatif, kualitatif dan RED. Bandung: Penerbit Alfabeta

Tibawi, A. L, 1972. Islamic Education. London: Luzac \& Company Ltd.

Yafie, Alie. 1996. Pandangan Islam Tentang Kewirausahaan dan Etos Kerja, dalam buku Ruh Islam dalam Budaya Bangsa (Agama dan Problem masa kini). Jakarta: PT Bina Rena Pariwara

Zuhairini, 1995. Filsafat Pendidikan Islam. Jakarta: Bumi Aksara 
282 Millah Vol. XIV, No. 2, Februari 2015 